msh-mss Mathématiques et sciences humaines

193 | Printemps 2011

Varia

\title{
Marc Barbut et la "loi de Pareto"
}

Marc Barbut and Pareto's Law

Bernard Valade

\section{OpenEdition}

\section{Journals}

Édition électronique

URL : http://journals.openedition.org/msh/11990

DOI : $10.4000 / \mathrm{msh} .11990$

ISSN : $1950-682$

\section{Éditeur}

Centre d'analyse et de mathématique sociales de l'EHESS

\section{Édition imprimée}

Date de publication : 15 janvier 2011

Pagination : 57-66

ISBN : 09876936

ISSN : 0987-6936

\section{Référence électronique}

Bernard Valade, "Marc Barbut et la "loi de Pareto" », Mathématiques et sciences humaines [En ligne], 193 | Printemps 2011, mis en ligne le 01 juin 2011, consulté le 23 juillet 2020. URL : http:// journals.openedition.org/msh/11990; DOI : https://doi.org/10.4000/msh.11990

Ce document a été généré automatiquement le 23 juillet 2020

(c) École des hautes études en sciences sociales 


\title{
Marc Barbut et la "loi de Pareto"
}

\author{
Marc Barbut and Pareto's Law
}

Bernard Valade

\section{RÉSUMÉS}

Formulée par Vilfredo Pareto à la fin du XIXe siècle, la loi de la répartition des revenus a donné lieu à nombre d'études d'économistes, de sociologues - de mathématiciens aussi. C'est aux aspects mathématiques de la distribution des richesses que Marc Barbut s'est attaché, au fil d'articles recueillis dans "La mesure des inégalités ", en mettant l'accent sur le caractère probabiliste du raisonnement paretien. Il lui revient notamment d'avoir souligné la portée des objections exprimées par Georges Sorel, montré comment Pareto s'est trompé sur le paramètre intrinsèque de la distribution, et dégagé les raisons pour lesquelles ce dernier n'est pas allé plus avant dans la voie qu'il a ouverte.

Formulated in the late 19 th century, Vilfredo Pareto's law of income distribution has led to a number of studies by economists, sociologists - and also mathematician. In several articles collected in "La mesure des inégalités", Marc Barbut examined the mathematical aspects of the distribution of wealth by emphasising the probabilistic character of the Pareto argument. His most important contributions reside in pointing out the impact of Georges Sorel's objections, in showing how Pareto was wrong about the intrinsic parameter of the distribution, as well as in revealing the reasons why Pareto decided to stop working in the direction he had initially taken.

\section{INDEX}

Mots-clés : homme moyen, inégalités, probabilité, répartition

Keywords : average man, cumulative distribution, inequalities, probability 


\section{AUTEUR}

\section{BERNARD VALADE}

Faculté des sciences humaines et sociales, Université Paris-Sorbonne, 45, rue des Saints-Pères 75006 Paris, berval@paris-sorbonne.fr 